
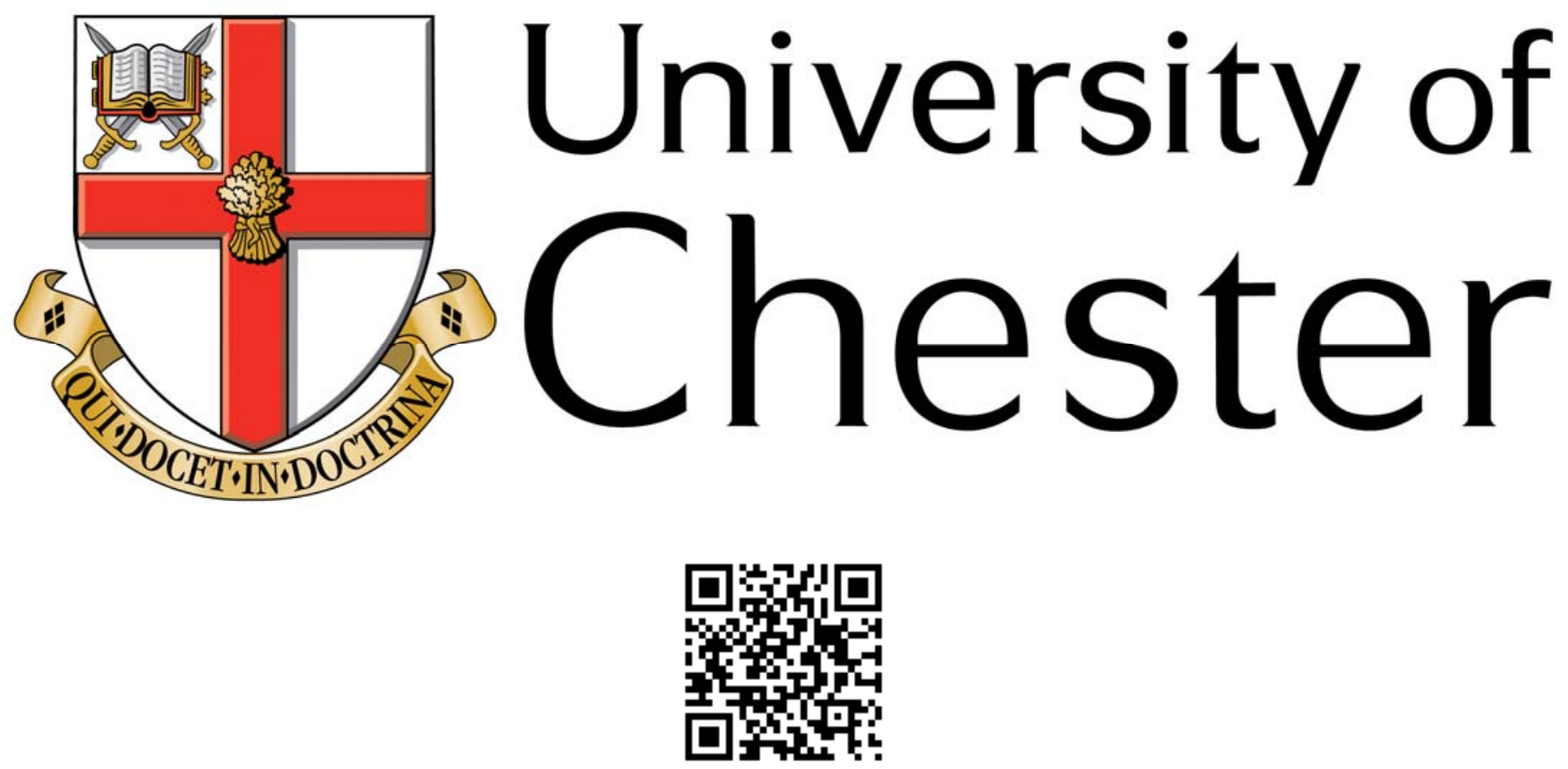

This work has been submitted to ChesterRep - the University of Chester's online research repository

\title{
http://chesterrep.openrepository.com
}

Author(s): David Clough

Title Angels, beasts, machines, and men: Configuring the human and nonhuman in Judaeo-Christian tradition

Date: 2008

Originally published in: Eating and believing

Example citation: Clough, D. (2008). Angels, beasts, machines, and men:

Configuring the human and nonhuman in Judaeo-Christian tradition. In R. Muers, \& D. Grumett (Eds.), Eating and believing (pp. 60-69). London: T\&T Clark

Version of item: Author's post-print

Available at: http://hdl.handle.net/10034/133869 
Clough, David. 'Angels, Beasts, Machines, and Men: Configuring the Human and Nonhuman in Judaeo-Christian Tradition’ In Eating and Believing. Edited by Rachel Muers and David Grumett. London: T\&T Clark, 2008, 60-69.

[Top of page 60]

\section{ANGELS, BEASTS, MACHINES, AND MEN: CONFIGURING THE HUMAN AND NONHUMAN IN JUDAEO-CHRISTIAN TRADITION}

David Clough

In 'The Animal That Therefore I Am (More to Follow)', Jacques Derrida presents, via a meditation on being seen naked by his cat, a persuasive deconstruction of the term 'animal':

Confined within this catch-all concept, within this vast encampment of the animal, in this general singular, within the strict enclosure of this definite article ('the Animal' and not 'animals'), as in a virgin forest, a zoo, a hunting or fishing ground, a paddock or an abattoir, a space of domestication, are all the living things that man does not recognize as his fellows, his neighbors, or his brothers. And that is so in spite of the infinite space that separates the lizard from the dog, the protozoon from the dolphin, the shark from the lamb, the parrot from the chimpanzee, the camel from the eagle, the squirrel from the tiger or the elephant from the cat, the ant from the silkworm or the hedgehog from the echidna. I interrupt my nomenclature and call Noah to help insure that no one gets left on the ark. ${ }^{1}$

This meditation poses a theological problem. Establishing the place of human beings in relation to the rest of creation has been an enduring concern throughout the Judeo-Christian tradition. From the

\footnotetext{
${ }^{1}$ Jacques Derrida, and David Wills, 'The Animal That Therefore I Am (More to Follow)', Critical
} Inquiry 28, 2 (2002), pp. 369-418 (402). 
opening two chapters of Genesis to the discovery in the 1980s that humans and chimpanzees have 98.4\% of their DNA in common, Jews and Christians have puzzled over how human beings are like and unlike their fellow creatures, and what this means for their respective places in creation. The qualities singled out to distinguish humans from nonhuman animals have been diverse: the ability to walk erect, the ability to reason, the use of language, and the possession of an immortal soul, among many others. But the concern to establish and regulate the boundary between the human and nonhuman in order to maintain the significance of the former is impressive in its continuity across millennia, with alternative positions becoming definitive of atheism, or at the very least heterodoxy.

[Top of page 61]

I have two interests in interrogating the theological significance of the distinction between human and nonhuman life. The first is simply intellectual curiosity: it is not immediately apparent, at least to me, why Jewish and Christian thinkers should have considered the definition of this boundary of such crucial importance, which encourages me to seek possible reasons for their concern. My second interest is more immediate and pressing: my judgment is that the way in which the line between human and nonhuman has been drawn and the significance given to it is both theologically and ethically problematic. This chapter is part of a wider project to critique and modify this demarcation, and thereby set out a new foundation for thinking theologically about human beings and other animals.

In this chapter, I cannot hope to present a fully supported argument for a particular reading of the theological discussion of this topic. Instead, I offer four snapshots from the Judaeo-Christian tradition, and argue in conclusion that Derrida, like Darwin before him, makes clear that existing theological accounts of human and nonhuman animals are inadequate. 
The work of the first century Jewish thinker Philo of Alexandria is a good place to start, both chronologically and because of the clear and uncompromising stance he adopted on the place of animals. This is clearest in a passage from his Questions and Answers on Genesis, where he is responding to the question of why, in the Great Flood, all the animals should die along with human beings, since animals cannot sin. Philo’s response is threefold. First, since when a king is slain in battle, the whole kingdom is also crushed, so since the human race is by analogy sovereign over the animals, God thought it reasonable that they should also be destroyed. Philo's second argument is also by analogy: he says when a person's head is cut off, no one blames nature if other parts die with it, and since human beings are the head and chief of the animals, it is not strange if the animals are destroyed with them. Thirdly, he observes that 'as wise men reason', animals were not originally made for their own sakes, but to serve humankind. Therefore it is reasonable that animals should be destroyed with the human beings for whose sake they exist. ${ }^{2}$

In his treatise On Creation, Philo rejects anthropomorphic interpretations of the creation of humanity in the image of God in favour of making the human mind the form of the divine image, arguing that the position of the human mind within the human body is analogous to the position God occupies in the world. ${ }^{3}$ Philo's concern to establish the pre-eminence of human beings within creation is made clear later in the creation treatise when he discusses the problem of why humanity was created last of the creatures, suggesting its inferiority. He provides four illuminating reasons to explain this apparent anomaly. First, he says that just as those hosting a banquet or gymnastic contest do not invite their guests until all their entertainers are gathered, so God wished human beings to find a feast and a great spectacle on coming into the world. Second, arriving in a world

\footnotetext{
${ }^{2}$ Philo, Quaestiones et solutiones in Genesim, bk 2, q. 9 (cf. the similar question in bk 1, q. 94), in Philo Suppl. I (trans. F.H. Colson and G H. Whitaker; London: Heinemann, 1929).

${ }^{3}$ Philo, De opificio mundi, $§ ~ 23$, in Philo I (trans. F.H. Colson and G.H. Whitaker; London: Heinemann, 1929).
} 
provided with abundance would be instructive to future generations that they were to spend their days without toil or trouble. Third, God wanted to unite the beginning and

[Top of page 62]

end of creation, and having started with heaven, finished with the being that is 'a miniature heaven'. Finally, humanity was created last so that its sudden appearance would amaze the other animals and make them do homage to their ruler. ${ }^{4}$

Philo's discomfort with continuity between the human and nonhuman parts of creation is also illustrated in his belief that the first two chapters of Genesis describe the creation of two different kinds of human being: the first made in the image of God, the second moulded from the earth as the other creatures are. The second being is of rather dubious status: it is not fit to serve God by caring for the garden, and after being placed in the garden soon runs away and is cast out. ${ }^{5}$ Later in his allegorical interpretation of Genesis, the relationship between human beings and the wild beasts and birds that attack them is likened to the relationship between the understanding soul and the passions that assail it: ${ }^{6}$ for Philo, the soul is unearthly and rational, while the earth and the creatures made from it are irrational and wild.

Philo's treatise On the Animals was translated from the Armenian only in 1981. It narrates a dialogue between Philo and his apostate nephew Alexander, though a dialogue without a great deal of interaction: a monologue from Alexander makes up the first two-thirds, and is followed by a monologue from Philo. Alexander observes that men subjugated women because they considered women weaker, and that when they saw other animals bending over the earth when humans walked upright, they differentiated themselves from the other animals and held them in disdain. He is

\footnotetext{
${ }^{4}$ Philo, De opificio mundi, $\S \S 25-28$.

${ }^{5}$ Philo, Legum allegoria, bk $1, \S 16$, in Philo I.

${ }^{6}$ Philo, Legum allegoria, bk 2, § 4.
} 
concerned to establish that animals should be helped by human beings without hesitation, and argues his case by asserting that nonhuman animals possess a rationality that is imperfect but fundamental to understanding their existence. ${ }^{7}$ Multifarious examples follow, which a brief sample will suffice to illustrate. The spider, Alexander notes, is proficient in various web designs and produces them without co-workers or tools. ${ }^{8}$ The intelligence of the bee is hardly distinguishable from the abilities of the human mind in contemplation. ${ }^{9}$ The swallow demonstrates prudence in its nest-building. ${ }^{10}$ The ability of animals to learn skills is impressive: monkeys can be taught to drive chariots, fawns to dance and do tricks, and the performance of circus animals is not merely comical but worthy of high regard. ${ }^{11}$ Alexander comments that 'nature has placed a sovereign mind in every soul $^{, 12}$ and claims that every creature is possessed of wisdom and discernment: they make plans to catch other animals, seek shelter from predators and human beings, and medicate themselves with herbs when ill. ${ }^{13}$ Animals are commendable examples of sexual self-restraint, engaging in sexual relations only for the purpose of reproduction, and the most virtuous abstain from eating flesh. ${ }^{14}$ After a long catalogue of such examples, Alexander concludes:

It is obvious that not only men but also various other animals have inherited the faculty of

\footnotetext{
${ }^{7}$ Philo of Alexandria, Philonis Alexandrini: De animalibus (trans. Abraham Terian; Chico, CA:
} Scholars, 1981), §§ 10-12. This association between women and nonhuman animals is a recurrent one in the tradition and has led me to use the gender-exclusive term 'men' in my title to avoid ignoring this gender issue.

${ }^{8}$ Philo, De animalibus, $\S \S 17-19$.

${ }^{9}$ Philo, De animalibus, $§ 20$.

${ }^{10}$ Philo, De animalibus, $§ 22$.

${ }^{11}$ Philo, De animalibus, $\S \S 23-25$.

${ }^{12}$ Philo, De animalibus, § 29.

${ }^{13}$ Philo, De animalibus, $§ \S 30-9$.

${ }^{14}$ Philo, De animalibus, $\S 48, \S 62$. 
reason. Furthermore it is believed that they possess both virtues and vices. An excuse is considerately made for those who have neither heard such a subject nor studied it on their own and so have remained in ignorance. But to those who have been endowed by God and natural agencies with fundamentals of knowledge and who have been instructed orally, it is fair to speak angrily as to laggards and enemies of truth. ${ }^{15}$

[Top of page 63]

Philo’s response is succinct and dismissive of these claims. Spiders and bees do not act by skill or reason, but just work diligently; birds fly, fish swim and land animals walk by nature, not by learning. All apparently foresightful action by nonhuman animals is involuntary. ${ }^{16}$ They have good qualities but are not rational, 'for reasoning ability extends itself to a multiplicity of abstract concepts in the mind's perception of God, the universe, laws, provincial practices, the state, state affairs, and numerous other things, none of which animals understand'. ${ }^{17}$ In conclusion, Philo states that inaccurately to ascribe capacities to animals diminishes human beings: 'Let us now stop criticizing nature and committing sacrilege. To elevate animals to the level of the human race and to grant equality to unequals is the height of injustice. To ascribe serious self-restraint to indifferent and almost invisible creatures is to insult those whom nature has endowed with the best part. ${ }^{, 18}$

\section{RABBINIC LITERATURE: ANGELS AND BEASTS}

Later Jewish sources seem a little more at ease than Philo with the idea of humans sharing attributes

\footnotetext{
${ }^{15}$ Philo, De animalibus, $\S 70$.

${ }^{16}$ Philo, De animalibus, $§ \S 77-80$.

${ }^{17}$ Philo, De animalibus, $§ 85$.

${ }^{18}$ Philo, De animalibus, § 100.
} 
with the animals. The Talmud says that of the six main characteristics of human beings, three make them like the angels and three like the beasts. Like the angels they understand, walk erect, and speak in the holy tongue; like the beasts they eat and drink, procreate, and relieve themselves. ${ }^{19}$ Genesis Rabbah pictures God making peace between the celestial and terrestrial worlds through a creature partaking in the immortality of the celestial sphere and the reproduction characteristic of earthly beings (12:8). This image is later amplified as human beings given four animal attributes and four angelic attributes: like the animals they eat and drink, procreate, excrete and die; like the angels they stand upright, speak, understand and see (14:3). ${ }^{20}$ Similarly in Leviticus Rabbah, the creation of human beings in Genesis 2 is pictured as the union of the lower spheres, formed from dust, with the upper spheres, through the enlivening breath of God. ${ }^{21}$

Concerning the significance of humans being created last, there is agreement with Philo. Talmudic and Midrashic texts state that humankind was last in creation, but first in thought. Human beings were contemplated before the creation of the world, and the world came into being only to serve their needs. ${ }^{22}$ Elsewhere, the Talmud echoes Philo’s explanation that being created last allowed humans to enter straight into the banquet God had prepared for them. ${ }^{23}$ There is, however, one alternative explanation: that humans were created last so they may be reminded that even the

\footnotetext{
${ }^{19}$ Hagiga 16a, Babylonian Talmud, cited in Eilon Schwartz, 'Mastery and stewardship, wonder and connectedness', in Judaism and Ecology: Created World and Revealed Word, ed. Hava TiroshSamuelson (Cambridge, MA: Harvard University Press, 2002), pp. 93-106 (98).

${ }^{20}$ Gen. Rabbah 14:3, cited in Noah J. Cohen, Sa`ar Ba`aley Hayim : The Prevention of Cruelty to Animals: Its Bases, Development and Legislation in Hebrew Literature (Jerusalem: Feldheim,
} 1976), p. 32.

${ }^{21}$ Lev. Rabbah 9:9, cited in Cohen, Sa`ar Ba`aley Hayim, p. 32.

${ }^{22}$ Gen. Rabbah 1:4; Sanhedrin 98b, cited in Cohen, Sa`ar Ba`aley Hayim, p. 32.

${ }^{23}$ Schwartz, 'Mastery and stewardship’, p. 98. 
gnats preceded them in the order of creation. ${ }^{24}$ Another text in Genesis Rabbah cites Rabbi Yehuda saying that everything in creation has a purpose, even those things people may consider unnecessary, such as flies, fleas and mosquitoes. ${ }^{25}$

While these Talmudic and Midrashic texts are more tolerant of commonalities between humans and animals than Philo seems to be, there is common ground in the view of creation as for the sake of human beings. In these Rabbinic accounts, humans are half earthly and half heavenly, suspended between the two spheres and establishing a relationship between them. ${ }^{26}$

[Top of page 64]

\section{MAIMONIDES AND AQUINAS: CITIES, RULERS AND CLOCKS}

The twelfth century Jewish thinker Moses Maimonides is a particularly interesting figure in tracing Judaeo-Christian views on animals. This is partly because he is a point of contact between the Rabbinic tradition and Aristotle, partly because he is constitutive of the Jewish philosophical tradition that followed him ${ }^{27}$ and influential on Thomas Aquinas among other Christian theologians,

\footnotetext{
${ }^{24}$ Sanhedrin 38a; Lev. Rabbah 14:1, cited in Cohen, Sa`ar Ba`aley Hayim, p. 32.

${ }^{25}$ Gen. Rabbah 10:8, cited in Judaism and Ecology, ed. Aubrey Rose (London: Cassell, 1992), p.
} 59.

${ }^{26}$ Elijah Judah Shochet's conclusion that in these texts animals should be seen as 'an intricately shaped and valuable tool loaned to man for his use' (Animal Life in Jewish Tradition: Attitudes and Relationships (New York: Ktav, 1984), p. 78) is perhaps too extreme, and is contradicted by other modern commentators who stress other elements in the tradition (e.g. Cohen, Sa`ar Ba`aley Hayim). ${ }^{27}$ Daniel Frank argues that Jewish philosophy is inconceivable without Maimonides, in 'Maimonides and medieval Jewish Aristotelianism', in The Cambridge Companion to Medieval Jewish Philosophy, eds Daniel H. Frank and Oliver Leaman (Cambridge University Press, 2003), 
and partly because he performed a rapid volte-face in his attitude to the place of human beings in the universe and their relationship with nonhuman animals.

In his early introduction to the Mishnah, Maimonides is resolutely anthropocentric in his interpretation of the world. Everything exists for the sake of humankind: some animals to be eaten or to serve other purposes such as carrying loads or speeding travel, and plants to be eaten or used as medicines. No herb, fruit or animal can fail to be beneficial to human beings, from the elephant to the worm, and Maimonides instructs his reader that 'if you find animals or plants that you think cannot be eaten and seem to have no purpose, you should blame it on your lack of knowledge. It is impossible for any herb, fruit or animal—from the elephant to the worm—not to be beneficial for man. ${ }^{28}$ In the later Guide of the Perplexed, however, Maimonides has changed his mind. ${ }^{29} \mathrm{He}$ agrees with Philo that the image of God in human beings is their unique possession of intellectual apprehension, ${ }^{30}$ but his disagreement with both Philo and the Rabbinic tradition over the place of humankind in the purposes of the universe is absolute.

It is sometimes thought, Maimonides observes, 'that the finality of all that exists is solely the existence of the human species so that it should worship God, and that all that has been made has been made for it alone so that even the heavenly spheres only revolve in order to be useful to it and to bring into existence that which is necessary for it’ ${ }^{31}$ He cites passages from the Prophets in

pp. 153-54.

${ }^{28}$ Moses Maimonides, Rambam: Maimonides’ Introduction to the Mishnah (trans. Rabbi A.Y. Finkel; Scranton, PA: Yeshivath Beth Moshe, 1993), p. 76.

${ }^{29}$ Abraham Joshua Heschel attributes this change to a loss of confidence in an anthropocentric universe following the death of his brother, in Maimonides: A Biography (trans. Joachim Neugroschel; New York: Farrar, Strauss and Giroux, 1982), p. 129.

${ }^{30}$ Moses Maimonides, The Guide of the Perplexed, 1:1 (trans. Shlomo Pines; Chicago, IL: University of Chicago Press, 1963).

${ }^{31}$ Maimonides, Guide, 3:13. 
support of this view, but then asks whether if we grant that the final end of creation is the existence of humankind, it would have been possible for God to have created human beings without all the preliminaries of the rest of creation. Maimonides considers it obvious that God could have done so, and argues that this means that the whole of nonhuman creation has been brought into existence without any final end at all, since its assumed final end, human beings, could have existed without any of them. Therefore 'it should not be believed that all the beings exist for the sake of the existence of man. On the contrary, all the other beings too have been intended for their own sakes and not for the sake of something else. ${ }^{32}$ Maimonides cites the verse from Proverbs, 'The Lord has made everything for a purpose' (16.4) as well as the first Genesis creation narrative affirming each part of creation as good without reference to any other part. To think that the world was created for humankind is like an individual in a city thinking that the final end of the city's ruler is to keep his house safe at night: from his point of view it looks like this, but only from his point of view. This does not entail radical egalitarianism between species for Maimonides: he believes plants were made to nourish animals and that humankind is the most noble earthly thing. ${ }^{33}$ But to acknowledge these differences between parts of creation is very different from believing that all things were

[Top of page 65]

created for the sake of human beings. In an earlier discussion about the problem of evil, he comments: 'Every ignoramus imagines that all that exists exists with a view to his individual sake; it is as if there were nothing that exists except him. ${ }^{34}$

\footnotetext{
${ }^{32}$ Maimonides, Guide, 3:13.

${ }^{33}$ Maimonides, Guide, 3:13.

${ }^{34}$ Maimonides, Guide, 3:12. James Diamond links this rejection of anthropocentrism to the humility Maimonides requires of the sovereign, in 'Maimonides on Kingship: The Ethics of Imperial Humility’, Journal of Religious Ethics 34, 1 (2006), pp. 89-114 (97).
} 
Christian theologians of the thirteenth century were indebted to Maimonides, and particularly to the way he integrated reflection on biblical texts and traditions of interpreting them with key emphases in Aristotelian thought. But Christian reception of Maimonides could clearly not be uncritical, and the Errors of the Philosophers, a work from the mid-thirteenth century attributed to Giles of Rome, lists fifteen errors through which the author views Maimonides as conceding too much to the scientists, thus making him worse than Pelagius! ${ }^{35}$ Thomas Aquinas depends on Maimonides for the way he construes the relationship between reason and revelation, God's knowledge, logical absurdity and omnipotence, and creation in time. ${ }^{36}$ His interpretation of the hierarchical ordering of creation means, however, that he cannot follow Maimonides in denying that the rest of creation exists for the sake of humankind: 'Less perfect things are ordered to the more perfect, just as a man is first of all alive, then an animal, and finally a man, so such things as plants that have merely life exist for animals, and animals exist for man. ${ }^{37}$ While God's providence conserves all living things in being, plants and animals are not conserved for their own sake, but for the sake of human beings. Therefore humans have no duties to animals, and biblical injunctions against animal cruelty are merely aimed at opposing habits that would lead to cruelty towards

${ }^{35}$ Cited in Leon Roth, The Guide for the Perplexed: Moses Maimonides (London: Hutchinson, 1948), pp. 86-87.

${ }^{36}$ For a survey, see Charles Singer, and Dorothea Singer, 'Jewish elements in thirteenth-century scholasticism', in Studies in Maimonides and St. Thomas Aquinas, ed. Jacob I. Dienstag (Bibliotheca Maimonidica; Texts, Studies, and Translations in Maimonidean Thought and Scholarship, 1; New York: KTAV, 1975), pp. 169-83, and in the same volume Zevi Diesendruck, 'Maimonides and Thomas Aquinas', pp. 184-91. Aquinas cites Maimonides twenty-five times in

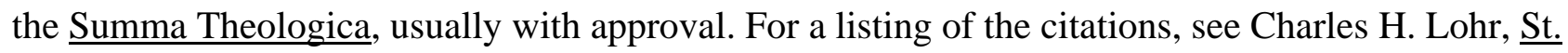
Thomas Aquinas: Scriptum Super Sententiis: An Index of Authorities Cited (Amersham: Avebury, 1980).

${ }^{37}$ Thomas Aquinas, Summa Theologica, IIaIIae, q. 64, a. 1 (60 vols.; London: Blackfriars, 1963). 
human beings. ${ }^{38}$ Animals are irrational and unable to make choices: their actions appear purposeful only because God has set within them a natural inclination to pursue their ends, just as human art sets arrows and clocks in motion. ${ }^{39}$ They are therefore unable properly to possess goods, so it is improper even to consider them objects of charity. ${ }^{40}$

When Aquinas discusses whether human beings were originally masters over all the creatures, he claims that 'in some sense or another all things are in man, and therefore in the measure that he holds sway over what is in himself, in the same measure it falls to him to hold sway over other things'. He explains that human beings share reason with the angels, 'sense forces’ (vires $\underline{\text { sensitivas) }}$ with the animals, 'natural vital forces' (vires naturales) with the plants, and the body itself with inanimate objects. Just as reason holds sway in human beings, so human beings hold sway over everything in the world that does not have reason, that is, everything except the angels. ${ }^{41}$

Aquinas cites Maimonides's view that it is foolish to think that the heavenly bodies were made for the sake of human beings, when considering the question of whether the brightness of the heavens will be increased when the world is renewed. He considers Maimonides's argument that 'it were not a wise craftsman who would make very great instruments for the making of a small work', and human beings are very small compared with the heavenly bodies. Aquinas answers that 'although the heavenly bodies far surpass the human body, yet the rational soul surpasses the heavenly bodies far more than these surpass the human body'. Therefore, he argues, 'it is not unreasonable to say that the heavenly bodies were made for man's sake' so long as it is recalled that the principal end of all things is God. ${ }^{42}$

\footnotetext{
${ }^{38}$ Thomas Aquinas, Summa Contra Gentiles, bk III, ch. 112 (5 vols.; Notre Dame, IN: University of Notre Dame Press, 1975).

${ }^{39}$ Aquinas, Summa Theologica, IaIIae, q. 13, a. 2.

${ }^{40}$ Aquinas, Summa Theologica, IIaIIae, q. 25, a. 3.

${ }^{41}$ Aquinas, Summa Theologica, Ia, q. 96, a. 3.

${ }^{42}$ Aquinas, Summa Theologica, suppl., q. 91, a. 3.
} 
[Top of page 66]

While Aquinas's view that it is appropriate to say that all things were made for the sake of human beings seems to place him in the same anthropocentric position as Philo, the final provision of this argument denotes a decisive difference in emphasis with the potential to lead to a very different view of the respective place of human and nonhuman animals in God's purposes. Aquinas's caution that it is only appropriate to speak of the heavenly bodies being made for the sake of human beings if one recalls that God is the principal end of all things points to a theocentric position rather than an anthropocentric position. In fact, emphases elsewhere in Aquinas suggest that human beings are not God's sole end in creation. In the Summa Contra Gentiles, he explains that diversity in creation is vital in order to communicate divine goodness: 'Inasmuch as every created substance must fall short of the perfection of the divine goodness, it was needful to have diversity in things for the more perfect communication of the divine goodness, that what cannot perfectly be represented by one created exemplar, might be represented by divers such exemplars in divers ways in a more perfect manner. ${ }^{43}$ In the Summa Theologica, Aquinas makes an analogous argument. When discussing whether the inequality in created things originates in God, he affirms that God did not make everything equal in creation, but also observes that the universe is perfect only because it exhibits different grades of goodness in different creatures. ${ }^{44}$ He also agrees with Philo’s nephew Alexander that animals can demonstrate prudence. ${ }^{45}$ Aquinas's view of creation is

${ }^{43}$ Summa Contra Gentiles, bk III, ch. 97, quoted in Thomas Aquinas, Of God and His Creatures (trans. Joseph Ricaby; London: Burns \& Oates, 1905), p. 260.

${ }^{44}$ Aquinas, Summa Theologica, Ia, q. 47, a. 2.

${ }^{45}$ Aquinas, Summa Theologica, IaIIae, q. 13, a. 2. See Judith A. Barad, Aquinas on the Nature and Treatment of Animals (San Francisco: International Scholars, 1995), ch. 6, pp. 95-112, for a survey of Aquinas's estimation of the capacities of nonhuman animals. 
resolutely hierarchical: human beings undoubtedly have the highest place, but the purposes of God's creation of nonhuman creatures are not exhausted in the utility of those creatures for human beings. $^{46}$

Before leaving Aquinas behind, we should note a very different mode in which he discusses animals: as allegories with meaning for human life. For example, when discussing the rationale for the ceremonial law of Israel, he explains why animals were considered clean and unclean: 'An animal that chews the cud and has a divided hoof is clean because it signifies the distinction of the two Testaments, or of the Father and the Son, or of the two natures in Christ, or of good and evil; and chewing the cud signifies meditation on the Scriptures and the right understanding of them. ${ }^{47}$ Similarly, the eagle stands for pride, the griffon for the cruelty of the powerful, the osprey for those who oppress the poor, the kite for those who are fraudulent, and the vulture for those who rejoice in death and fighting. And so on, and so on, for another thirteen species in this section alone.

\section{DESCARTES AND MALEBRANCHE: HUMAN SOULS AND BEAST MACHINES}

Four centuries after Aquinas’s passing comparison of animals with clocks, René Descartes became fascinated with comparing animals with the machines of the seventeenth century, and planned a magnetic man-machine and two different machines simulating animals. He also spent time

${ }^{46}$ Judith Barad argues in $\underline{\text { Aquinas }}$ that his ontology of nonhuman animals as each possessed of its own degree of perfection does not fit with his judgement that they are not deserving of moral consideration, and recommends that this inconsistency be resolved in favour of his ontological view. Dorothy Yamamoto offers a more pessimistic reading of Aquinas in this context in 'Aquinas and animals: patrolling the boundary?’, in Animals on the Agenda: Questions About Animals for Theology and Ethics, eds Andrew Linzey and Dorothy Yamamoto (London: SCM, 1998), pp. 8089.

${ }^{47}$ Aquinas, Summa Theologica, IaIIae, q. 102, a. 6. 
dissecting animals. He concluded that 'if there were ... machines which had the organs and appearance of a monkey or of some other irrational animal, we would have no means of recognizing that they were not of exactly the same nature as these animals', whereas we could

[Top of page 67]

identify supposedly human machines because they could not use words to convey thoughts, or adapt themselves to act like reasonable human beings in a wide variety of circumstances. For Descartes, this shows the difference between humans and animals: their lack of speech means that animals not only have less reason than human beings, 'but that they have none at all', because it is otherwise unbelievable that not even the most talented parrot or monkey could equal the achievements of the 'most stupid child' ${ }^{48}$

Both Descartes and his contemporaries considered major theological commitments to be at stake in the question of whether animals were merely machines. Following the argument I have just outlined, Descartes explains that the question of animal souls is important because 'there is nothing which leads feeble minds more readily astray from the straight path of virtue than to imagine the soul of animals is of the same nature as our own'. This is because we then think we have no more to fear or hope for after this life than flies or ants, whereas once we appreciate our difference from animals, we understand why human souls are 'entirely independent of the body' and do not die with

${ }^{48}$ René Descartes, Discourse on Method and Other Writings (trans. F.E. Sutcliffe; Harmondsworth: Penguin, 1968), pp. 74-75. The argument based on language as a unique human possession was given new vigour by its adoption by Noam Chomsky in Language and Mind (New York: Harcourt Brace Jovanovitch, 1968), p. 10. It must be brought into question, however, by examples of chimpanzees and gorillas communicating successfully in sign language. For an overview of some of these studies, see Nancy R. Howell, 'The Importance of Being Chimpanzee', Theology and Science 1, 2 (2003), pp. 179-91. 
it. ${ }^{49}$ Descartes may have also shared the concern that the doctrine of the afterlife would become implausible if the humblest animal possessed an immortal soul. ${ }^{50}$ Descartes is inconsistent on the question of whether animals feel pain, ${ }^{51}$ but for one of his most ardent adherents, Nicolas Malebranche, this belief is the conclusion to a simple but crucial theological argument. ${ }^{52}$ Malebranche cites Augustine’s view that under a just God, no one suffers who has not deserved it. Since animals cannot sin, he reasons, they cannot justly be subjected to suffering. Therefore, despite all appearances, animals cannot suffer pain. Malebranche complains at his lack of success persuading others to set aside the evidence of their senses in favour of this incontrovertible argument, noting that in so doing 'one risks exposing oneself to the laughter of superficial and inattentive minds, ${ }^{53}$ In Objectiones sextae, published with the first edition of the Meditations, a group of theologians warned that if animals could be thought of as pure automata, then same would

${ }^{49}$ Descartes, Discourse on Method and Other Writings, p. 76.

${ }^{50}$ For an example of one theologian who developed an account of the afterlife with a place for all creatures, see John Hildrop, ‘Free Thoughts upon the Brute Creation: In Two Letters to a Lady’, in Miscellaneous Works of John Hildrop, vol. 1, pp. 159-294 (London: Rivington, 1754), reprinted in Animal Rights and Souls in the Eighteenth Century, ed. Aaron Garrett (London: Thoemmes, 2000). ${ }^{51}$ For a discussion of this question, see John Cottingham, ““A Brute to the Brutes?” Descartes’ Treatment of Animals', Philosophy 53 (1978), pp. 551-61; and Peter Harrison, 'Descartes on Animals’, The Philosophical Quarterly 42, 167 (1992), pp. 219-27.

52 This is, I believe, the worst theological argument I have come across, though readers may have their own candidates for this honour.

${ }^{53}$ Nicolas Malebranche, The Search After Truth (Cambridge University Press, 1997), pp. 323-24. Leonora Cohen Rosenfield documents the way Cartesian vivisectionists mocked those who pitied the animals subject to their cruel experiments, in From Beast-Machine to Man-Machine (New York: Oxford University Press, 1941), p. 54. 
be said of human beings. ${ }^{54}$ This prophecy was fulfilled in the work of La Mettrie, whose 1747 work

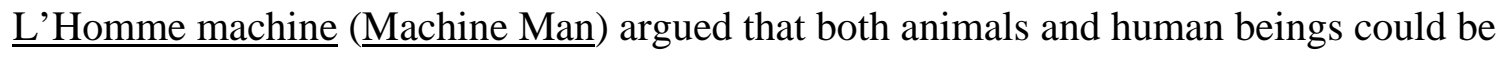
understood as machines. ${ }^{55}$

\section{WHERE ARE THE ANIMALS?}

In his commentary on his translation of Philo’s De animalibus, which I discussed above, Abraham Terian makes an odd observation: 'In spite of the title of the treatise and the frequent references to animals, the work as a whole is basically anthropological. ${ }^{, 56}$ In other words, Philo embarks on this careful natural history not primarily to understand the animals he describes, but to defend the position that human beings are the only rational creatures. In the dialogue, they function as landmarks on a map intended to identify the location and boundaries not of animal life, but of human life, or perhaps just the life of the wise man. This purpose is made explicit in the allegorical interpretation of the flood narrative, where men in the story stand for the mind, and animals for either the senses or the passions. ${ }^{57}$

[Top of page 68]

\footnotetext{
${ }^{54}$ Rosenfield, From Beast-Machine to Man-Machine, p. 10. In the pages that follow, Rosenfield notes the debate about Descartes' theological motivations, concluding: 'One sometimes suspects that the religious aspect of Descartes' reasoning about the beast-machine was above all a selfdefense and a means of gaining approbation for his revolutionary thesis.’ (23)

55 Julien Offray de La Mettrie, Machine Man and Other Writings (ed. Ann Thomson; Cambridge University Press, 1996).

${ }^{56}$ Philo, De animalibus, $\S 112$.

${ }^{57}$ Philo, Quaestiones et solutiones in Genesim, bk 1, q. 94; bk II, q. 9.
} 
We should note that elsewhere, allegorical interpretations read women in the same way. Stories of the world therefore become just a way of redescribing the human—or male—condition.

This raises a larger question. If, in his discussions of animals, Philo is not talking about animals at all, what of the rest of the Judaeo-Christian tradition? The question is an unsettling one. In the Rabbinic literature I have surveyed, animals are largely placeholders for the creaturely elements in human beings, rather than beings of intrinsic interest. Aquinas's use of the different species of animals as examples of human sins is precisely an instance of talking about animals in order to talk about human beings. His use of an individual human being as a metaphor for the whole of creation is arguably an even more obvious example of failing to attend adequately to nonhuman creation, though he does come closer to recognizing the particularity of nonhuman animals when discussing their capacities and contribution to the perfection of creation. When we turn to Descartes and Malebranche it is clear that concerns about the human soul, or God's justice, are central:

Descartes objects to the belief that other animals have souls because it makes the Christian doctrine of the immortality of the soul less credible; Malebranche is concerned that God would seem unjust if animals were thought to suffer without having sinned. Maimonides is the only figure in my brief survey who sees clearly that nonhuman parts of creation must have been created as ends in themselves, and not for their utility to human beings. His is a rare perspective that runs against the grain of the bulk of discussion treating animals only as they relate to human identity or interests.

Derrida’s gestures indicating the oddity of collapsing all but one of the 1.25 million species of living creature into the singular 'animal' encourage the belief that this term manifests little interest in the species falling under the term. Instead, following Philo, Jewish and Christian thinkers — as well as the philosophical traditions that came in their wake ${ }^{58}$ - have used 'animal' to prop up constructions of the human, and are usually not discussing 'animals' even when they appear to be doing so. For those who are interested in the development of a theology that does

\footnotetext{
${ }^{58}$ Derrida considers that all preceding philosophers— ' Aristotle to Heidegger, from Descartes to
} Kant, Lévinas and Lacan'—have failed to see the problematic of 'animal', in 'The Animal', p. 396. 
attend to nonhuman animals, the significance of this is double-edged. First, it seems hopeful, given the previous lack of attention to this topic, if there is more room for manoeuvre. On the other side, however, the position of nonhuman animals is so closely tied to theological anthropology in the tradition that it seems there will have to be significant developments in a theology of the human in order to make space for an adequate theology of the nonhuman. As recipients of God's revelation and covenant promise, however, Jews and Christians have no reason for insecurity about the place of human beings in God's good purposes, and no need to establish their identity at the cost of diminishing the importance of others of God's creatures. We stand in need of a theological description of the human and nonhuman that gives due account to each. To affirm that God watches over me, my co-religionists, or my species, is not inconsistent with believing that these purposes are not the sum of God's purposes in the creation and redemption of the universe. Over one hundred years ago, Charles Darwin showed that the difference between human and nonhuman animals was a difference of degree rather than kind, but

[Top of page 69]

theologians have been slow learners in this context. ${ }^{59}$ Theological readings of the human and 'animal' remain resolutely pre-Darwinian, let alone pre-Derridean. A new account is required, not only to do justice to the particularity of the other creatures God made alongside human beings, but to rescue theological anthropology from implausibility and incoherence as well.

\footnotetext{
${ }^{59}$ Charles Darwin, The Descent of Man, and Selection in Relation to Sex (London: Murray, 1871). In fact, one could argue that theologians have had considerably longer than a century to come to terms with this issue. Luther's commentary on Genesis, for example, already demonstrates awareness and consequent concern at what human and nonhuman animals have in common. See Martin Luther, Lectures on Genesis, Chapters 1-5 (ed. Jaroslav Pelikan; Luther’s Works, 1; Saint Louis, MO: Concordia, 1958).
} 